\title{
Validation of genomic predictions for a lifetime merit selection index for the US dairy industry
}

\author{
Brenda Fessenden, ${ }^{1} \odot$ Daniel J. Weigel, ${ }^{2}$ Jason Osterstock, ${ }^{1}$ David T. Galligan, ${ }^{3}$ and Fernando Di Croce ${ }^{1 *}$ () \\ ${ }^{1}$ Zoetis Genetics, 333 Portage Street, Kalamazoo, Ml 49007 \\ ${ }^{2}$ Zoetis Outcomes Research, 333 Portage Street, Kalamazoo, MI 49007 \\ ${ }^{3}$ University of Pennsylvania School of Veterinary Medicine, New Bolton Center 382 West Street Road, Kennett Square, PA 19348
}

\begin{abstract}
Selection indices are a critical component of many breeding programs. A common purpose of a selection index is to predict an animal's genetic potential for total economic merit. The objective of this study was to evaluate retrospectively whether a specific selection index comprising genomically-enhanced predicted transmitting abilities had the ability to predict observed lifetime profit in US Holstein animals. The selection index evaluated was dairy wellness profit (DWP\$). In total, 2,185 animals were included in this study. Index values were used to rank and assign animals to quartiles (genetic groups: worst $25 \%, 26-50 \%, 51-75 \%$, and best 25\%). Generalized linear mixed effects models were applied to estimate the associations between index quartile and defined economic outcomes. Similar analyses were conducted to estimate associations between index quartile and observed phenotype to characterize the extent to which profitability outcomes were driven by economically relevant production and health traits. Differences in lifetime profit and annuity value between the best and worst genetic groups for DWP $\$$ were $\$ 811$ $( \pm 297)$ and $\$ 232( \pm 88)$, respectively. Significant differences were also observed between top and bottom quartiles for milk production $(8,077 \mathrm{~kg})$, fat production $(336 \mathrm{~kg})$, protein production $(264 \mathrm{~kg})$, live calves $(0.5)$, time spent in the lactating herd $(6.6 \mathrm{mo})$, and cow mortality $(8.4 \%)$. Additionally, differences in disease incidence were significant between the best and worst DWP $\$$ quartiles for metritis (5.2\%), mastitis (14.9\%), and lameness (15.9\%). The observed results of this study demonstrated the ability of DWP $\$$ predictions to predict lifetime profitability of Holstein animals and its potential utility as a tool to guide selection and breeding programs. Improving DWP\$ through genetic selection, when combined with good management practices,
\end{abstract}

Received March 10, 2020.

Accepted June 26, 2020.

*Corresponding author: fernando.dicroce@zoetis.com provides an opportunity for dairy producers to improve overall herd profitability.

Key words: Holstein, selection index, genomicallyenhanced predicted transmitting ability, profitability

\section{INTRODUCTION}

Selection indices are a critical component of many breeding programs. They were first developed in the 1940s to facilitate selection for balanced genetic improvement across multiple genetic traits related to production and economic outcomes (Hazel, 1943). Selection indices provide a way to combine information about many traits into a single number that can rank animals and inform breeding decisions (Cole and VanRaden, 2018). A common approach to development of a selection index is to predict an animal's genetic potential for total economic merit (Shook, 2006). Historically, selection indices throughout the world have focused on improving production traits (Byrne et al., 2016). The effect of increased production on herd profitability was a motivator of this selection goal. However, this narrow selection goal contributed to a decrease in health and fertility (VanRaden, 2004). Improvement of phenotype recording and development of new trait evaluations led to fertility (VanRaden et al., 2004), longevity (VanRaden and Wiggans, 1995), milk quality (Schutz, 1994), and health traits (Vukasinovic et al., 2017) becoming available to breeders. Over the last 25 years, incorporation of these nonproduction traits in selection indices has grown (Miglior et al., 2005) as breeders strive to account for factors influencing both income from animal production and associated costs of production. Selection schemes across the globe are working toward this goal as Cole and VanRaden, 2018 demonstrate in a comparison of 21 selection indices from 15 countries.

Selection indices are a common component of commercial genomic test offerings. Dairy producers may seek to improve their herds by testing heifers and ranking them based upon a selection index to inform culling and breeding decisions (Weigel et al., 2012). The dairy 
industry benefits from genomic technology because it results in faster genetic progress (García-Ruiz et al., 2016; Hill, 2016). At the farm level, genetic values are increasingly applied to inform culling decisions and the application of advanced reproductive technologies. Clearly, as the rate of genetic progress increases, it becomes more important to have a selection index that is correctly formulated for the goal of lifetime profit.

Historically, much of selection index evaluation has been based on the perception of researchers, industry experts, and dairy producers (Shook, 2006; Byrne et al., 2016) in regards to the extent in which economic weights, trait emphasis in the selection index, and expected genetic progress for traits align with factors perceived to affect profitability of a dairy operation. Although university studies have demonstrated the results from single trait selection (Boettcher, et al., 1993), there is a need to determine whether selection indices accurately predict differences in animal profitability in real-world settings. In Ireland (Ramsbottom et al., 2012) and Australia (Newton et al., 2017), this methodology is starting to be developed. Building upon these methodologies, our study's objective was to estimate the associations between an economic selection index derived from genomically-enhanced predicted transmitting abilities (gPTA) and observed lifetime profit in US Holstein animals. A secondary objective was to evaluate the associations between an economic selection index and observed phenotypes that contribute to lifetime profit of an animal.

Dairy Wellness Profit (DWP\$) is an economic selection index that includes production, fertility, functional type, longevity, calving ability, milk quality, cow and calf wellness traits, and polled test results. It was formulated to estimate the potential lifetime profit an animal would generate under US dairy economic conditions. In the current study, we hypothesized that animals with the highest genetic DWP $\$$ would have higher observed lifetime profit than animals with the lowest genetic DWP\$.

\section{MATERIALS AND METHODS}

\section{Experimental Design}

This study followed an observational retrospectivecohort design. A power calculation was run to determine the size of population needed to detect a statistically significant difference in lifetime profit between 2 genetic groups, where the difference in lifetime profit is $20 \%$ of the mean of the population. The power calculation indicated that the minimum number of animals per herd was 180 with an $\alpha$ value of 0.05 and a $\beta$ value of 0.8 , according to methodology described by (Dohoo et al., 2003). This study was designed to have an $80 \%$ probability of detecting a significant difference at the $\alpha=0.05$ level if true differences were at least $20 \%$ between genetic groups. The power calculations estimated that a population of 900 animals would be sufficient to detect statistically significant differences in lifetime profit of $20 \%$ between the 2 best and worst genetic groups.

\section{Phenotypic Data and Economic Evaluation}

Herds and Animals. Five US dairy herds (average 2,531 lactating cows) that used commercial genomic tests were included in this study based upon the following criteria: (1) were of sufficient size to have at least 180 genomic tested Holstein females born in 2011, (2) recorded health events at an incidence similar to the national incidence in the wellness trait evaluation for at least 3 of 6 health events (Vukasinovic et al., 2017), (3) recorded milk, fat, and protein production on a per-animal basis, (4) recorded breeding and calving data, and (5) recorded when an animal left the herd and whether that animal was sold or died. Data were obtained from dairy herds located in Wisconsin, South Dakota, and Idaho. To be enrolled in this study, individual animals needed to meet the following criteria: (1) born in 2011, (2) had received a genomic evaluation before December 2012, and (3) entered the lactating herd as a first lactation animal. Production and health data between January 1, 2011 and April 12, 2019 were extracted from herd management software. In total, 2,185 animals met the criteria and were included in this study. Key phenotypic variables for the animals included in this study are shown in Table 1.

Data Collection and Editing. Individual events and recorded production occurring between January 1, 2011 and the age at which an animal died or was removed from the herd were included in the analysis. Animals were excluded from the study population if they were removed from the herd before calving, were missing consecutive lactation data (e.g., recorded observations for lactations 1 and 3 , but not lactation 2), or if there was a lapse in data recorded but no removal date had been recorded. Of the 2,185 animals included in the study, 64 were still alive at the time of final data collection. For the purposes of analysis, any animals still in the herd were considered as sold and received a $\$ 875$ salvage value. Herds were not routinely monitored or compensated for data recording by Zoetis.

Lifetime Profit. For each animal, the individual lifetime profit was calculated using the following equation: 
Table 1. Phenotypic variables for animals included in the study

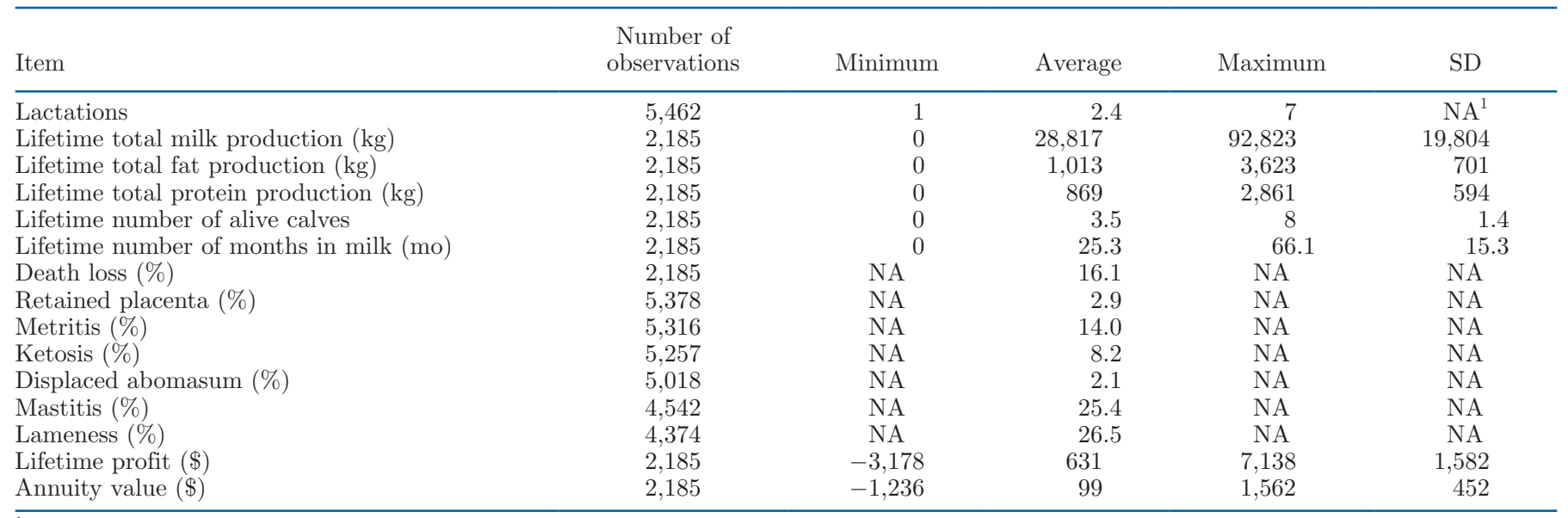

${ }^{1} \mathrm{NA}=$ not applicable.

$$
\begin{gathered}
\text { Lifetime profit }=\$_{\text {iofc }}+\$_{\text {calf }}+\$_{\text {salvage }}-\$_{\text {heifer }} \\
-\$_{\text {breeding }}-\$_{\text {disease }}-\$_{\text {genomic }}-\$_{\text {other_costs }} .
\end{gathered}
$$

Economic assumptions used for each income and expense are found in Table 2. Component values were derived as follows.

Income over feed cost $\left(\$_{\text {iofc }}\right)$ was calculated using the following formula:

$$
\begin{aligned}
& \$_{\text {iofc }}=\left(\mathrm{ECM}_{\mathrm{v}}-\text { netmargin } \times \mathrm{ECM}_{\mathrm{d}}-\text { maintcst }_{\mathrm{d}}\right) \\
& \times \text { lactation days in milk }-\left(\text { maintcst }_{\mathrm{d}} \times \text { days dry }\right),
\end{aligned}
$$

where netmargin was the marginal feed cost per kilogram of milk; maintcst $t_{d}$ represented maintenance cost of feed per cow per day, the assumptions for which are found in Table 2; $\mathrm{ECM}_{\mathrm{d}}$ represented energy-corrected milk per day. The $\mathrm{ECM}_{\mathrm{d}}$ was calculated using the following formula (Tyrrell and Reid, 1965; DHIA, 2000):

$$
\begin{aligned}
& \mathrm{ECM}_{\mathrm{d}}=(0.327 \times \text { lactation total milk production } \\
& +12.95 \times \text { lactation total fat production }+7.65 \\
& \times \text { lactation total protein production }) / \text { days in milk. }
\end{aligned}
$$

$\mathrm{ECM}_{\mathrm{v}}$ represented the dollar value of production per day and was calculated as follows:

$\mathrm{ECM}_{\mathrm{v}}=(\$ 0.0164 \times$ lactation total milk production

$+\$ 5.80 \times$ lactation total fat production $+\$ 5.95 \times$

lactation total protein production)/days in milk.

The coefficient for total milk was the net value after accounting for the $\$ 0.57 / \mathrm{kg}$ value of the $0.0569 \mathrm{~kg}$ of other solids, a charge of $\$ 0.013 / \mathrm{kg}$ for hauling, and $\$ 0.003 / \mathrm{kg}$ for marketing charges.

An animal's $\$_{\text {iofc }}$ was determined for each lactation and animal in the herd. The $\$_{\text {iofc }}$ from all lactations were summed together to determine lifetime value. Calf value $\left(\$_{\text {calf }}\right)$ was the summation of the value of all live calves produced in an animal's lifetime. This was calculated for each lactation an animal freshened and summed together to determine the lifetime value. Salvage value $\left(\$_{\text {salvage }}\right)$ was the salvage value an animal generated when leaving the herd. If an animal died, the salvage value was $\$ 0$ because it was assumed none of the salvage value was recovered. Because it was difficult to determine why an animal left the herd, salvage value was determined based upon the parity of the animal at time of culling. This was done to approximate the animal's BW at time of removal, which is detailed in Table 2. Heifer-raising cost $\left(\$_{\text {heifer }}\right)$ was calculated by multiplying an animal's age at first calving by the economic assumption of daily cost to raise a heifer. Breeding cost $\left(\$_{\text {breeding }}\right)$ was the summation of the cost of all breedings that happened in an animal's lifetime. Disease cost $\left(\$_{\text {disease }}\right)$ was the summation of the treatment costs, increased labor costs, and discarded milk cost of all disease events that happened in an animal's lifetime. Genomic cost $(\$$ genomic $)$ was the assumed cost for genetic testing with CLARIFIDE Plus (Zoetis Inc., Florham Park, NJ).

Other costs $\left(\$_{\text {other_costs }}\right)$ were calculated by multiplying daily operational costs by total number of days in the lactating and dry herd and were used to account for items such as supplies, fuel, marketing, insurance, taxes, utilities, labor, bedding, repairs, and depreciation. Importantly, all incomes and expenses for each animal were adjusted to account for the time value of 
Table 2. Assumptions used in lifetime profit calculation

\begin{tabular}{lcl}
\hline Item & Value & Source \\
\hline Heifer raising cost $(\$ / \mathrm{d})$ & 2.30 & Dhuyvetter and Overton, 2017 \\
Genomic test cost $(\$)$ & 43 & Zoetis US, 2020 \\
Marginal feed cost per kg of milk $(\$)$ & 0.13 & NRC, 2001; Galligan and Wu, 2013; USDA-NASS, \\
& & 2019 \\
Fat value $(\$ / \mathrm{kg})$ & 5.80 & VanRaden, et al., 2018; USDA-AMS, 2020 \\
Protein value $(\$ / \mathrm{kg})$ & 5.95 & VanRaden, et al., 2018; USDA-AMS, 2020 \\
Other solids value $(\$ / \mathrm{kg})$ & 0.57 & VanRaden, et al., 2018; USDA-AMS, 2020 \\
Hauling cost $(\$ / \mathrm{kg})$ & 0.013 & VanRaden, et al., 2018 \\
Marketing cost $(\$ / \mathrm{kg})$ & 0.003 & USDA-AMS, 2016 \\
Other solids $(\%)$ & 5.69 & NRC, 2001 \\
Maintenance cost $(\$ / \mathrm{d})$ & 2.13 & NRC, 2001 \\
Cull value $(\$ / \mathrm{kg})$ & 1.10 & USDA-NASS, 2019 \\
Live calf value & 100 & Galligan and Wu, 2013 \\
First lactation BW $(\mathrm{kg})$ & 572 & Zoetis US, 2018 \\
Second lactation BW $(\mathrm{kg})$ & 704 & Zoetis US, 2018 \\
Third+ lactation BW $(\mathrm{kg})$ & 793 & Zoetis US, 2018 \\
Breeding cost $(\$)$ & 40 & Galvão et al., 2013 \\
Other cost $(\$)$ & 3.62 & Dhuyvetter et al., 2007 \\
Mastitis cost $(\$)$ & 81 & Bar et al., 2008; Cha et al., 2011; Cha et al., 2014 \\
Lameness cost $(\$)$ & 49 & Guard, 2008b \\
Metritis cost $(\$)$ & 70 & Guard, 2008a \\
Retained placenta cost $(\$)$ & 70 & Guard, 2008a \\
Displaced abomasum cost $(\$)$ & 189 & Guard, 2008a \\
Ketosis cost $(\$)$ & 39 & Guard, 2008a \\
Cow respiratory disease cost $(\$)$ & 110 & Galligan and Wu, 2013 \\
Milk fever cost $(\$)$ & 40 & Guard, 2008a \\
Calf respiratory disease cost $(\$)$ & 17 & Galligan and Wu, 2013 \\
Calf scours cost $(\$)$ & 32 & Galligan and Wu, 2013 \\
\hline & & \\
\hline
\end{tabular}

money relative to the start of the investment using a present value calculation. In this analysis, start of investment in an animal was defined to be at birth.

Net Present Value. The net present value (NPV) formula (Brealey et al., 2012) used is listed below:

$$
N P V=C_{o}+\Sigma C_{t} /(1+r)^{t},
$$

where $N P V$ was the summation of total expenses and income for an animal through her lifetime, accounting for the time value of money; $C_{o}$ represented the initial investment in the animal; $C_{t}$ represented each additional expense or income for the animal; $r$ represented the annual discount rate of $10.5 \%$ (Galligan, 2006); $t$ represented the time period that passed between the expense or return date and the animal's birthdate, and was divided by $365 \mathrm{~d}$ to put time on a year basis.

Each individual expense or income that an animal experienced ( $\left.\$_{\text {calf }}, \$_{\text {salvage }}, \$_{\text {breeding }}, \$_{\text {disease }}, \$_{\text {genomic }}\right)$ had a separate time period based on the date of the event. The expenses and income for each lactation $\$$ iofc time period was defined as the time between an animal's mid-lactation date and birthdate. The time period of $\$_{\text {heifer }}$ investment was the midpoint between an animal's first lactation fresh date and birth date. An animal's $\$_{\text {other_costs }}$ time period was the time between the middle of an animal's time in the lactating herd and birthdate.
Annuity Value. Annuity value was calculated to account for the differing lifespans of the animals in the study. This resulted in profit values expressed for a 1 -yr period. The annuity value was calculated for each animal using the formula below (Brealey et al., 2012):

$$
C_{\text {Annuity }}=\frac{N P V}{(1 / r-1) /\left[r(1+r)^{t}\right]},
$$

where $N P V$ was the summation of total investments made in an animal through her lifetime accounting for the time value of money; $r$ represented the annual discount rate of $10.5 \%$ (Galligan, 2006); $t$ represented the time period that passed between the investment date and the animal's birthdate and was divided by $365 \mathrm{~d}$ to put the time on a year basis.

The final result of the economic evaluation was lifetime profit expressed in $N P V$ and lifetime profit expressed as an annuity value.

\section{Evaluation of Genetic Merit}

Animals from enrolled herds, originally submitted to Zoetis for genomic testing, were genotyped with 2 versions of the low-density chips: Illumina Bovine3K 
Table 3. Summary statistics for gPTA ${ }^{1}$ or $\mathrm{gSTA}^{2}$ of traits and subindices included in Dairy Wellness Profit for animals included in this study

\begin{tabular}{|c|c|c|c|c|}
\hline Index or trait & Minimum & Average & Maximum & $\mathrm{SD}$ \\
\hline Dairy Wellness Profit $^{1}$ & -450 & 223 & 797 & 171 \\
\hline Milk $^{1}$ & $-1,410$ & 417 & 2,372 & 528 \\
\hline Protein ${ }^{1}$ & -29 & 14 & 66 & 13 \\
\hline Fat $^{1}$ & -47 & 23 & 80 & 19 \\
\hline Productive life ${ }^{1}$ & -3.6 & 2.1 & 7.0 & 1.6 \\
\hline Cow livability ${ }^{1}$ & -5.5 & 0.6 & 5.6 & 1.6 \\
\hline SCS & 2.35 & 2.86 & 3.44 & 0.14 \\
\hline Body size composite $^{1}$ & -3.04 & -0.03 & 2.95 & 0.86 \\
\hline Udder composite $^{1}$ & -2.02 & 0.78 & 3.06 & 0.73 \\
\hline Feet and legs composite ${ }^{1}$ & -1.67 & 0.86 & 3.02 & 0.67 \\
\hline Daughter pregnancy rate ${ }^{1}$ & -3.8 & 0.44 & 3.4 & 1.1 \\
\hline Heifer conception rate ${ }^{1}$ & -4.2 & 0.76 & 4.2 & 1.2 \\
\hline Cow conception rate ${ }^{1}$ & -6.7 & 0.92 & 6.7 & 1.8 \\
\hline Calving ability $^{1}$ & -42.2 & 15.6 & 65.0 & 15.3 \\
\hline Mastitis $^{2}$ & 71 & 99 & 114 & 6 \\
\hline Lameness $^{2}$ & 74 & 100 & 114 & 6 \\
\hline Metritis $^{2}$ & 78 & 99 & 112 & 7 \\
\hline Retained placenta ${ }^{2}$ & 70 & 100 & 113 & 6 \\
\hline Displaced abomasum $^{2}$ & 77 & $\begin{array}{r}100 \\
99\end{array}$ & 111 & 5 \\
\hline Ketosis $^{2}$ & 69 & 98 & 111 & 6 \\
\hline Calf respiratory $^{2}$ & 75 & 97 & 114 & 7 \\
\hline Calf scours ${ }^{2}$ & 64 & 93 & 112 & 7 \\
\hline Calf livabilitv $^{2}$ & 71 & 95 & 110 & 6 \\
\hline
\end{tabular}

(Illumina Inc., San Diego, CA) and Illumina BovineLD (Boichard et al., 2012) by Zoetis Genetics Laboratory in Kalamazoo, Michigan (3-19K markers). Animals were nominated, along with pedigree and genotype to the Council on Dairy Cattle Breeding (CDCB) to obtain CDCB genetic evaluation predictions. The following trait gPTA were obtained from the December 2012 CDCB official evaluation release and included in calculation of DWP\$: milk, fat, protein, productive life, daughter pregnancy rate, heifer conception rate, cow conception rate, calving ability, SCS, body size composite, feet and leg composite, and udder composite. HornPoll test results were also obtained from the December 2012 CDCB official evaluation release. The rationale of using December 2012 CDCB predictions was to avoid including gPTA that may have included an animal's own performance records in the genetic evaluation. Cow livability was first released in August 2016; therefore, cow livability gPTA was used from the December 2016 official evaluation release, although the performance of the study animals may have been included in estimation of their gPTA for this trait.

For the wellness traits, low-density genotypes (3-19K markers) were imputed to 45,425 markers using available software (FImpute; Sargolzaei et al., 2014). Genomic PTA and associated reliabilities were estimated using the single step evaluation method (Misztal et al., 2009,2014 ) as previously described (Vukasinovic et al.,
2017; Gonzalez-Peña et al. 2019). Importantly, cow and calf wellness predictions were generated from phenotypic data available on December 31, 2012 to ensure that an animal's own performance data did not contribute to the genetic evaluation for the wellness traits.

Because this is a retrospective analysis, the goal was to generate gPTA, genomically-enhanced standardized transmitting ability (gSTA), and lifetime merit selection index values using genetic predictions that would have been available as a calf before entering production. Summary statistics for DWP $\$$, gPTA, and gSTA for all traits in DWP $\$$ for animals included in this study are in Table 3.

\section{Dairy Wellness Profit Selection Index}

In 2016, Zoetis Genetics developed the DWP\$ selection index, subsequently updated to include additional traits in 2018. Dairy Wellness Profit is a multitrait selection index that includes cow and calf wellness, production, fertility, functional type, longevity, livability, calving ability, and milk quality traits, as well as polled test results. The DWP $\$$ was derived using standard selection index theory (Hazel, 1943; Schneeberger et al., 1992). Development of an economic selection index happens in several stages. First, trait PTA, along with the phenotypic correlations, and genetic relationships between traits were estimated (VanRaden, 2004). Sec- 
ond, the economic value of each trait as it relates to the respective contributions to an animal's lifetime profitability was estimated. To calculate the economic value, all income and expenses for a 1-unit increase in a trait were determined (Gay et al., 2014; Byrne et al., 2016; Cole and VanRaden, 2018). The assumption was that all other traits remained constant at that time. Third, the selection index was constructed. The gPTA for each trait are multiplied by the corresponding economic weight and summed together to determine an animal's selection index value (VanRaden and Cole, 2014).

In the case of the cow and calf wellness traits, a literature review was conducted to inform the assumed cost per case for each calf- and cow-wellness trait. Cost per case of disease was multiplied by the industry incidence of disease (Vukasinovic et al., 2017) using the same methodology as the Nordic Total Merit Index (Pedersen et al., 2008). This resulted in the final economic weights for these specific wellness traits. Cost per case of calf respiratory disease and calf mortality were calculated using slightly different methodology. The calf's age when respiratory disease or mortality are experienced greatly affects the cost of the disease. Therefore, the cost per case of disease or mortality was calculated for 2 separate segments as follows: (1) 0 to $60 \mathrm{~d}$ of life for calf respiratory and 2 to $60 \mathrm{~d}$ of life for calf livability (representing the preweaning period) and (2) 61 to $365 \mathrm{~d}$ of life (representing the period between weaning and breeding). Calf respiratory and livability traits do not account for respiratory disease or mortalities after $365 \mathrm{~d}$ of life. Costs for calf traits were similarly multiplied by the industry incidence of disease or mortality for that age range (Gonzalez-Peña et al., 2019) and summed to derive the final economic weight.

Economic values associated with production, fertility, longevity, calving, milk quality, and functional type traits were derived using a similar approach to that used for Net Merit (NM\$) and Grazing Merit (GM\$) (Gay et al., 2014; VanRaden and Cole, 2014). Modifications were made to the base economic assumptions to address projected future economic values and additional findings from a literature review. Additionally, because the cost of disease was directly accounted for by the wellness traits, the economic values for production, fertility, longevity, and milk quality were modified from that of $\mathrm{NM} \$$ to ensure they did not include the indirect economic effect of disease. This prevented double-accounting of the economic cost of disease.

\section{Assigning Animals to Genetic Groups}

Dairy Wellness Profit predictions generated with the 2018 formulation were used to rank animals within herd and assign them to quartiles (genetic groups: worst $25 \%, 26-50 \%, 51-75 \%$, and best 25\%). This approach is similar to what has been reported by others (Weigel et al., 2012; McNeel et al., 2017)

\section{Statistical Analysis}

Data analysis for this paper was completed using SAS software version 9.4 (SAS Institute Inc. Cary, NC). Means were calculated using the PROC MEANS procedure in SAS. For all analyses, differences were deemed statistically significant when $P<0.05$. The primary dependent variables were lifetime profit and annuity value. Additional variables were analyzed as supporting data for the main objective of evaluating the model's ability to predict lifetime profit. Those variables were lifetime milk production, lifetime fat production, lifetime protein production, lifetime months in milk, lifetime number of live calves, and death loss.

Data were analyzed using the PROC MIXED procedure using the statistical model:

$$
Y=\mathbf{X} \beta+\mathbf{Z} \mu+e,
$$

where $Y$ represented lifetime profit or annuity value; $\beta$ represented the fixed effects of the genetic group (worst $25 \%, 26-50 \%, 51-75 \%$, best $25 \%$ ); $\mu$ represented the random effect of herd; and $e$ represented the residual with $\mathbf{X}$ and $\mathbf{Z}$ representing design matrices relating observations $Y$ to $\beta$ and $\mu$. When analyzing supporting data, $Y$ represented the supporting data phenotype and the rest of the statistical model remained the same. Marginal means and the standard error of the mean are reported.

Lactational disease incidence for the first 4 lactations was also analyzed as supporting data. For each lactation, health outcomes were converted to a binary $(0=$ no events, $1=$ at least 1 event) scale and were analyzed using PROC GLIMMIX with a binomial distribution and a logit link function in SAS version 9.3 using the statistical model:

$$
Y=\mathbf{X} \beta+\mathbf{Z} \mu+e,
$$

where $Y$ represented the phenotype; $\beta$ represented the fixed effects of the genetic group (worst $25 \%, 26-50 \%$, $51-75 \%$, best $25 \%$ ); $\mu$ represented the random effect of animal nested within herd and herd to account for repeated measures; and $e$ represented the residual with $\mathbf{X}$ and $\mathbf{Z}$ representing design matrices relating observations $Y$ to $\beta$ and $\mu$. Marginal means and the standard error of the mean were reported. 
Table 4. Least squares means and SEM of the genetic groups when animals are ranked by Dairy Wellness Profit (DWP\$) gPTA ${ }^{1}$

\begin{tabular}{|c|c|c|c|c|c|c|c|c|}
\hline $\begin{array}{l}\text { DWP } \$ \text { genetic } \\
\text { group }\end{array}$ & df & $\begin{array}{l}\text { Lifetime } \\
\text { profit (\$) }\end{array}$ & SEM & $P$-value & $\mathrm{df}$ & $\begin{array}{l}\text { Annuity } \\
\text { value }(\$)\end{array}$ & SEM & $P$-value \\
\hline $\begin{array}{l}\text { Worst } 25 \\
26-50 \\
51-76 \\
\text { Best } 25\end{array}$ & 2,177 & $\begin{array}{l}167^{\mathrm{a}} \\
561^{\mathrm{b}} \\
706^{\mathrm{b}} \\
978^{\mathrm{c}}\end{array}$ & $\begin{array}{l}297 \\
297 \\
297 \\
297\end{array}$ & $<0.0001$ & 2,177 & $\begin{array}{r}-45^{\mathrm{a}} \\
81^{\mathrm{b}} \\
116^{\mathrm{b}} \\
187^{\mathrm{c}}\end{array}$ & $\begin{array}{l}88 \\
88 \\
88 \\
88\end{array}$ & $<0.0001$ \\
\hline
\end{tabular}

${ }^{\mathrm{a}-\mathrm{c}}$ Marginal means within column and trait with different superscripts differ $(P<0.05)$.

${ }^{1} \mathrm{gPTA}=$ genomically enhanced predicted transmitting ability.

\section{RESULTS AND DISCUSSION}

\section{Lifetime Profitability for the Genetic Groups}

The observed results demonstrated the association between a lifetime merit selection index and prediction of lifetime profit. Differences in observed lifetime profit (marginal means) were statistically significant between DWP $\$$ genetic groups $(P<0.0001)$. As shown in Table 4 , differences in observed lifetime profit and annuity value between DWP $\$$ best and worst genetic groups was $\$ 811$ and $\$ 232$, respectively $(P<0.0001)$. This indicated that animals with higher DWP $\$$ predictions had higher observed lifetime profit and annuity value than animals with lower DWP $\$$ predictions. It follows that decisions made in selection, management, and breeding to increase average index value within a given herd would be expected to increase average profitability. Increasing profitability through direct selection of lifetime merit selection indices can play an important role in a comprehensive profit management strategy for dairy operations.

To calculate lifetime profit and annuity value, key observed phenotypic variables that affect profit were identified and extracted from herd management software. Economic assumptions were defined to monetize these observed phenotypic variables of the enrolled animals (Table 2). We did not have access to detailed economic information such as feed price or price at culling for each herd included in this study. These animals lived over a 9-yr period, and thus an animal most likely experienced different income and expenses due to market volatility and regional differences in prices. It is possible that the true realized lifetime profit and annuity values may have differed from those used in the analysis.

Selection indices affect decisions made today under a set of contemporary economic assumptions, yet they will also affect future generations of animals (Dekkers and Gibson, 1998). However, it is likely that in the future, dairy herds will be operating under different market conditions, government regulations, and consumer preferences than the dairy industry is experiencing today. The purpose of this study was not to forecast future profitability, but instead to help understand the implications of selection decisions made with DWP $\$$ for a given set of economic assumptions. Changes in the future, including additional traits of economic relevance or differences in the cost or income structure of dairy production, may necessitate reconsideration and revision of economic selection indices.

\section{Lifetime Profitability Regression Analysis}

A regression analysis was conducted to assess the actual lifetime profit and annuity value change per point of DWP $\$$. The resulting analysis demonstrated that for every 1-point increase in DWP\$, there was a $\$ 1.84(P<0.0001)$ and a $\$ 0.52(P<0.0001)$ increase in observed lifetime profit and annuity value, respectively. The expected relationships between DWP $\$$ and lifetime profit is a slope of $\$ 2$, as DWP $\$$ is presented on a transmitting ability scale and individual animals express the full complement of their breeding value, not solely the proportion they pass to future progeny. There are potentially many factors that may contribute to this discrepancy. One factor is the formulation of DWP\$ itself. Phenotypic variables could exist that affect lifetime profit, but a genetic prediction for that variable may not be included in DWP\$. Furthermore, there is a degree of uncertainty associated with trait economic value estimates, which could reduce the predictive capability of the selection index. Economic value errors that change the direction of selection for an important trait, economically important traits not included, or placement of large economic values on unimportant traits can reduce the predictive capabilities of the selection index (Smith, 1983). Conducting a sensitivity analysis on the economic assumptions used to develop DWP\$ would help determine the effect of an incorrect economic assumption on DWP\$'s predictive capabilities.

A second factor is the observed phenotypic variables and economic assumptions used in the calculation of lifetime profit. There is potential for inconsistency between the economic assumptions applied to observed variables used for each income or expense generated by 
an animal (Table 2) and the true incomes and expenses experienced by the animals. Examples of this inconsistency would be the lack of recording for some health trait outcomes by some herds, actual treatment costs, the lack of accounting for differences in feed consumed due to genetic differences in body size composite, other herd costs, and the sole use of animals that calved at least once such that the effect of heifer fertility and health traits may be biased.

A third factor is the herd environmental level. The higher the herd environmental level, the greater the opportunity is for genetic differences to be expressed. Numerous studies have shown the effect of good management practices on an animal's ability to be productive in the herd (Ray et al., 1992; Barkema et al., 1998; Hudson et al., 2018). If animals did not experience an optimal environment for the duration of their time in the herd, their productive capabilities and lifetime profit could have been suppressed.

A fourth factor is the effect of the $10.5 \%$ discount rate on lifetime profit. When evaluating production and health outcomes over an extended period of time, it is important to account for the time value of money. If the discount rate was set to $0 \%$ instead of $10.5 \%$, the regression analysis demonstrated that for every 1-point increase in DWP $\$$, there was a $\$ 2.86(P<0.0001)$ increase in observed lifetime profit. At a discount rate of $10.5 \%$, incomes generated in the seventh lactation have been discounted by $50 \%$. The longer an animal stays in the herd, the greater the effect is of the discount rate on mature cow milk and salvage value.

Validation of selection indices have been performed in other countries. Evaluation of the Irish Economic Breeding Index (EBI; Ramsbottom et al., 2012) and the Australian Balanced Performance Index (BPI; Newton et al., 2017) found there was a relationship between increased selection index genetic merit and increased profitability. In the evaluation of EBI, Ramsbottom et al. (2012) expected to see a $€ 2$ increase in observed net margin for every 1-point increase of the EBI, and observed an actual difference of $€ 1.94$. In the evaluation of BPI, Newton et al. (2017) expected to see a $\$ 1$ increase in observed profit for every 1-point increase of BPI, and observed a $\$ 1.60$ to $\$ 2.28$ increase. There are some differences between these 2 studies and the study reported here. These 2 studies used actual financial information from the study herds to determine animal profitability, whereas our study applied economic assumptions to key observed phenotypic variables to calculate the lifetime profit. Neither the Irish nor Australian studies used genomically-enhanced selection index predictions in their analysis, but our study did. Ramsbottom et al. (2012) used whole-herd observed performance, and our study analyzed the observed per- formance of individual animals. Additionally, the definition of EBI was the expected profit per lactation, and Ramsbottom et al., 2012 estimated profit per lactation or year. The phenotypic records used by Newton et al. (2017) to calculate observed profit were also used in the cow Australian Breeding Value prediction generation (Newton et al., 2017). In addition to the part-whole relationship this creates, the cow Australian Breeding Value would also have higher reliability due to having increased information from relatives, such as parents, siblings, and offspring, all of which could contribute to BPI's predictive capabilities. In our study, we used gPTA that would have been available before calving and did not have an animal's own performance data contribute to the genetic evaluation, with the noted exception of cow livability. Although these selection indices have incorporated different traits and economic values than DWP $\$$, both of these studies had similar results to those reported here and show the potential of selection indices as a tool to improve herd profitability.

\section{Lifetime Performance for the Genetic Groups}

To better understand the association between DWP\$ and observed lifetime profit, the relationships between DWP $\$$ group and other observed phenotypic outcomes was examined. Table 5 shows the difference between the DWP $\$$ genetic groups for observed lifetime milk production $(P<0.0001)$, lifetime fat production $(P<$ $0.0001)$, lifetime protein production $(P<0.0001)$, the number of months in the lactating herd $(P<0.0001)$, number of live calves produced $(P<0.0001)$, and animal death loss $(P<0.0001)$. For the DWP $\$$ best and worst genetic groups, the difference in observed lifetime milk production was $8,077 \mathrm{~kg}$, the lifetime fat production was $336 \mathrm{~kg}$, and the lifetime protein production was $264 \mathrm{~kg}$. This translates to a $32.5 \%$ increase in lifetime milk production, a $39.3 \%$ increase in lifetime fat production, and a $35.7 \%$ increase in lifetime protein production between the DWP $\$$ best and worst genetic groups. Furthermore, we observed a difference of 0.5 live calves, which is a $21.7 \%$ increase between DWP\$ best and worst genetic groups. Our results indicated a difference of $6.6 \mathrm{mo}$ in the lactating herd, which is an increase of $29.3 \%$ between the DWP $\$$ best and worst genetic groups. We observed a difference of $8.4 \%$ in cow mortality, which is a $39.6 \%$ decrease between DWP $\$$ best and worst genetic groups. These results indicated that DWP $\$$ effectively ranks animals for observed phenotypic variables that affect an animal's profitability within the herd. An animal's ability to stay healthy throughout her life also has an effect on profitability. We observed differences between DWP $\$$ genetic groups for metritis $(P<0.0001)$, mastitis $(P<0.0001)$, and 
Table 5. Least squares means and SEM of the genetic groups when animals are ranked by Dairy Wellness Profit (DWP\$) gPTA ${ }^{1}$

\begin{tabular}{|c|c|c|c|c|c|}
\hline Phenotypic variable & $\begin{array}{l}\text { DWP\$ genetic } \\
\text { group }\end{array}$ & df & LSM & SEM & $P$-value \\
\hline Milk (kg) & $\begin{array}{l}\text { Worst } 25 \\
26-50 \\
51-76 \\
\text { Best 25 }\end{array}$ & 2,177 & $\begin{array}{l}24,846^{\mathrm{a}} \\
29,119^{\mathrm{b}} \\
30,729^{\mathrm{b}} \\
32,923^{\mathrm{c}}\end{array}$ & $\begin{array}{l}2,446 \\
2,443 \\
2,443 \\
2,444\end{array}$ & $<0.0001$ \\
\hline Fat $(\mathrm{kg})$ & $\begin{array}{l}\text { Worst } 25 \\
26-50 \\
51-76 \\
\text { Best } 25\end{array}$ & 2,177 & $\begin{array}{r}853^{\mathrm{a}} \\
1,008^{\mathrm{b}} \\
1,079^{\mathrm{b}} \\
1,189^{\mathrm{c}}\end{array}$ & $\begin{array}{l}83 \\
83 \\
83 \\
83\end{array}$ & $<0.0001$ \\
\hline Protein $(\mathrm{kg})$ & $\begin{array}{l}\text { Worst } 25 \\
26-50 \\
51-76 \\
\text { Best } 25\end{array}$ & 2,177 & $\begin{array}{r}739^{\mathrm{a}} \\
872^{\mathrm{b}} \\
922^{\mathrm{b}} \\
1,003^{\mathrm{c}}\end{array}$ & $\begin{array}{l}78 \\
78 \\
78 \\
78\end{array}$ & $<0.0001$ \\
\hline Live calves (number) & $\begin{array}{l}\text { Worst } 25 \\
26-50 \\
51-76 \\
\text { Best } 25\end{array}$ & 2,177 & $\begin{array}{l}2.3^{\mathrm{a}} \\
2.6^{\mathrm{b}} \\
2.7^{\mathrm{bc}} \\
2.8^{\mathrm{c}}\end{array}$ & $\begin{array}{l}1.5 \\
1.5 \\
1.5 \\
1.5\end{array}$ & $<0.0001$ \\
\hline Months in milk (mo) & $\begin{array}{l}\text { Worst } 25 \\
26-50 \\
51-76 \\
\text { Best } 25\end{array}$ & 2,177 & $\begin{array}{l}22.5^{\mathrm{a}} \\
25.8^{\mathrm{b}} \\
27.2^{\mathrm{b}} \\
29.1^{\mathrm{c}}\end{array}$ & $\begin{array}{l}47.0 \\
46.9 \\
46.8 \\
46.9\end{array}$ & $<0.0001$ \\
\hline Death loss $(\%)$ & $\begin{array}{l}\text { Worst } 25 \\
26-50 \\
51-76 \\
\text { Best } 25\end{array}$ & $\begin{array}{r}8 \\
11 \\
10 \\
12\end{array}$ & $\begin{array}{l}21.2^{\mathrm{a}} \\
14.1^{\mathrm{b}} \\
15.2^{\mathrm{b}} \\
12.8^{\mathrm{b}}\end{array}$ & $\begin{array}{l}2.9 \\
2.2 \\
2.3 \\
2.1\end{array}$ & $\leq 0.0002$ \\
\hline
\end{tabular}

${ }^{\mathrm{a}-\mathrm{c}}$ Marginal means within column and trait with different superscripts differ $(P<0.05)$.

${ }^{1}$ gPTA $=$ genomically enhanced predicted transmitting ability.

lameness $(P<0.0001)$. The observed difference between DWP $\$$ genetic group means were not statistically significant for retained placenta, ketosis, or displaced abomasum, which reflected the relative emphasis placed on those traits in the index. As shown in Table 6, differences in observed disease incidence between DWP $\$$ best and worst genetic groups was $0.2 \%$ for retained placenta, $5.2 \%$ for metritis, $0.3 \%$ for ketosis, $0.8 \%$ for displaced abomasum, $14.9 \%$ for mastitis, and $15.9 \%$ for lameness. These results indicated that DWP $\$$ ranked animals such that differences in phenotypic outcomes were in proportion to how that trait affected an animal's expenses. These results support the practice of using a selection index to make breeding and culling decisions instead of an individual trait or traits.

Though there were differences in observed disease incidence between DWP $\$$ best and worst genetic groups, these differences were conservative estimates of the size of difference because not all herds were recording all 6 health events discussed here. This could also result in a more conservative estimate of the effect of disease events on lifetime profit. Animals left their herd at different times throughout their life, and thus as lactation number increased, the number of animals in the analysis decreased. Additionally, animals in the worst DWP $\$$ genetic group left the herd sooner than animals in the best DWP $\$$ genetic group, as shown by an increase of $6.6 \mathrm{mo}$ in the lactating herd for the best DWP\$ genetic group. This means animals in the best DWP\$ group had more time at risk than animals in the worst DWP $\$$ group. This makes it difficult to estimate what the true incidence would have been by parity for each DWP $\$$ genetic group. The use of a statistical model that accounts for the correlation between lactations for the disease incidence analysis is likely inadequate at addressing this issue.

The differences in lifetime profit and phenotypic variables that contribute to lifetime profit between DWP\$ genetic groups may also have been underestimated due to the exclusion of animals culled before entering the lactating herd. The herds in the study would have used the gPTA to cull low-ranking heifers, and heifers with poor fertility and health genetics would be at a higher risk of not calving. This selection bias would have caused a shift in the population structure.

We were interested in understanding the relationship between lactation, disease incidence, and DWP\$ genetic groups. Although the lactation and DWP $\$$ genetic group interaction was not statistically significant for any of the disease traits, it was interesting to see the disease incidence by lactation and DWP $\$$ genetic group. Figure 1 shows the estimated back-transformed least squares means disease incidence of at least 1 occurrence of metritis, mastitis, and lameness for each 
DWP $\$$ genetic group by lactation for the first through fourth lactation. Animals in this study stayed beyond the fourth lactation; however, there were not enough animals in the fifth and sixth lactations for the statistical model to converge. Figure 1 shows that in each lactation, the best DWP $\$$ genetic group experienced less metritis, mastitis, and lameness incidence than the worst DWP $\$$ genetic group. As seen in other studies (Overton and Fetrow, 2008; McNeel et al., 2017), first lactation cows experienced the highest incidence of metritis; the worst DWP $\$$ genetic group experienced $16 \%$ metritis incidence and the best DWP $\$$ genetic group experienced $9 \%$ metritis incidence. Mastitis incidence increased with each lactation. It culminated in the highest incidence rate in the fourth lactation; the worst DWP $\$$ genetic group experienced $68 \%$ incidence of $\geq 1$ case of mastitis and the best DWP $\$$ genetic group experienced $58 \%$ incidence of mastitis. Lameness incidence also increased with each lactation. In the fourth lactation, the worst DWP $\$$ genetic group experienced $71 \%$ having $\geq 1$ case of lameness incidence and the best DWP $\$$ genetic group experienced $48 \%$ lameness incidence. The increase in mastitis and lameness incidence in older animal indicated that disease expenses increased as the animals aged. These levels of mastitis and lameness in multiparous animals are unacceptable at a farmer and industry level and merit additional selection pressure on these traits. However, it is known that mature animals have higher milk production (Ray et al., 1992), and therefore generate more production income. The relationship between animal age, production, and disease creates a need to directly select for genetic improvement in disease risk to create animals that can generate mature-animal milk without suppressing milk production due to disease or generating disease expenses. A lifetime merit selection index tries to find the balance between these different components that affect an animal's ability to generate profit throughout their entire life. The strong association between DWP\$ genetic groups and key phenotypic variables indicated that DWP\$ can predict performance across a wide range of phenotypic variables that contribute to lifetime profit.

\section{Effect of Individual Traits on Lifetime Performance}

Although profitability is important to many dairy producers, producers also frequently identify individual traits that are important to their genetics programs. We wanted to determine if genetic selection using a selection index resulted in an increase in genetic potential for underlying traits in the selection index. To

Table 6. Marginal means, disease incidence, and SEM of the genetic groups when animals are ranked by Dairy Wellness Profit (DWP\$) gPTA ${ }^{1}$ for retained placenta, metritis, ketosis, displaced abomasum, mastitis, and lameness

\begin{tabular}{|c|c|c|c|c|c|}
\hline Health event & $\begin{array}{l}\text { DWP\$ } \\
\text { genetic } \\
\text { group }\end{array}$ & df & $\begin{array}{c}\text { Disease incidence } \\
\text { (marginal mean, \%) }\end{array}$ & SEM & $P$-value \\
\hline \multirow[t]{4}{*}{ Retained placenta } & Worst 25 & 5.7 & $2.5^{\mathrm{a}}$ & 1.2 & \multirow[t]{4}{*}{0.59} \\
\hline & $26-50$ & 5.1 & $2.4^{\mathrm{a}}$ & 1.1 & \\
\hline & $51-76$ & 5.9 & $1.7^{\mathrm{a}}$ & 0.8 & \\
\hline & Best 25 & 5.0 & $2.3^{\mathrm{a}}$ & 1.0 & \\
\hline \multirow[t]{4}{*}{ Metritis } & Worst 25 & 4.0 & $10.5^{\mathrm{a}}$ & 6.2 & \multirow[t]{4}{*}{$<0.0001$} \\
\hline & $26-50$ & 4.0 & $6.4^{\mathrm{b}}$ & 3.9 & \\
\hline & $51-76$ & 4.0 & $6.9^{\mathrm{b}}$ & 4.2 & \\
\hline & Best 25 & 4.0 & $5.3^{\mathrm{b}}$ & 3.3 & \\
\hline \multirow[t]{4}{*}{ Ketosis } & Worst 25 & 3.5 & $1.1^{\mathrm{ab}}$ & 1.9 & \multirow[t]{4}{*}{0.16} \\
\hline & $26-50$ & 3.5 & $0.9^{\mathrm{ab}}$ & 1.6 & \\
\hline & $51-76$ & 3.5 & $1.1^{\mathrm{a}}$ & 1.9 & \\
\hline & Best 25 & 3.5 & $0.8^{\mathrm{b}}$ & 1.5 & \\
\hline \multirow[t]{4}{*}{ Displaced abomasum } & Worst 25 & 3.5 & $1.4^{\mathrm{a}}$ & 0.2 & \multirow[t]{4}{*}{0.08} \\
\hline & $26-50$ & 2.9 & $1.1^{\mathrm{abc}}$ & 1.3 & \\
\hline & $51-76$ & 2.9 & $1.2^{\mathrm{ab}}$ & 1.7 & \\
\hline & Best 25 & 3.3 & $0.6^{\mathrm{c}}$ & 1.4 & \\
\hline \multirow[t]{4}{*}{ Mastitis } & Worst 25 & 4.7 & $42.4^{\mathrm{a}}$ & 8.2 & \multirow[t]{4}{*}{$<0.0001$} \\
\hline & $26-50$ & 4.5 & $37.4^{\mathrm{a}}$ & 7.8 & \\
\hline & $51-76$ & 4.5 & $28.2^{\mathrm{b}}$ & 6.7 & \\
\hline & Best 25 & 4.5 & $27.5^{\mathrm{b}}$ & 6.6 & \\
\hline \multirow[t]{4}{*}{ Lameness } & Worst 25 & 4.0 & $37.5^{\mathrm{a}}$ & 27.2 & \multirow[t]{4}{*}{$<0.0001$} \\
\hline & $26-50$ & 4.0 & $30.0^{\mathrm{ab}}$ & 24.4 & \\
\hline & $51-76$ & 4.0 & $22.9^{\mathrm{bc}}$ & 20.5 & \\
\hline & Best 25 & 4.0 & $21.6^{\mathrm{c}}$ & 20.0 & \\
\hline
\end{tabular}

${ }^{a-c}$ Marginal means within column and trait with different superscripts differ $(P<0.05)$.

${ }^{1} \mathrm{gPTA}=$ genomically enhanced predicted transmitting ability. 
a)

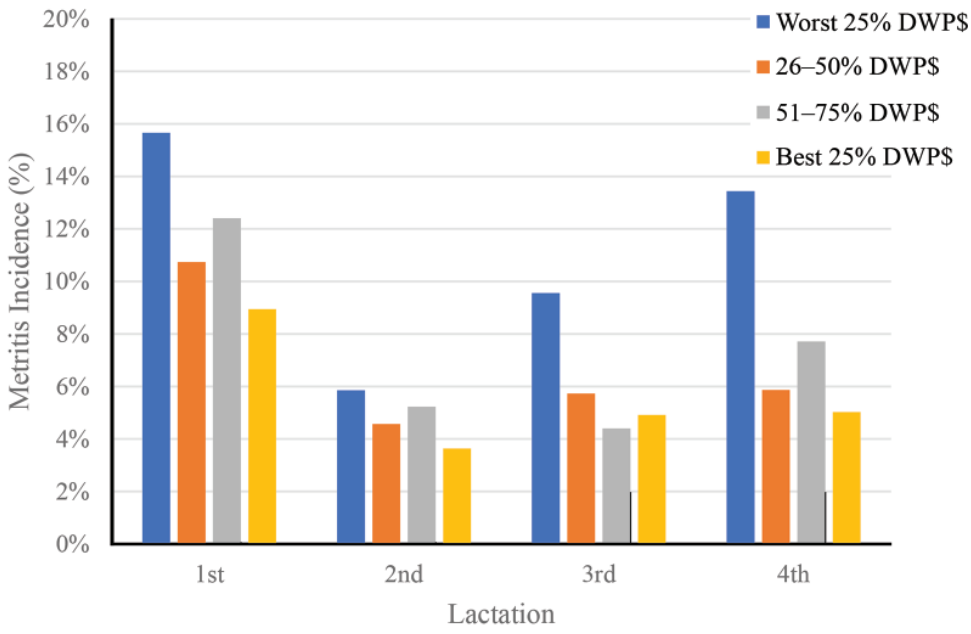

b)

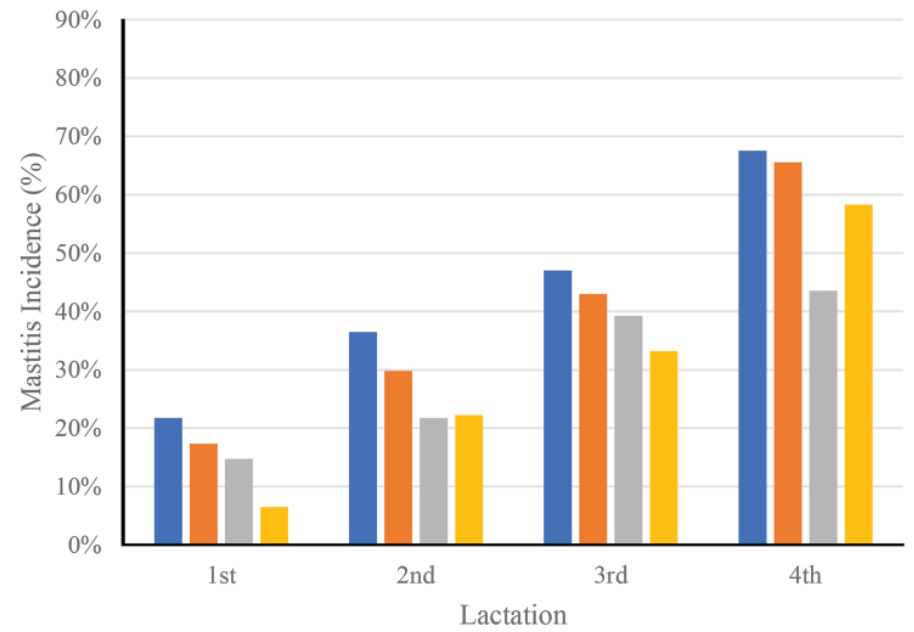

c)

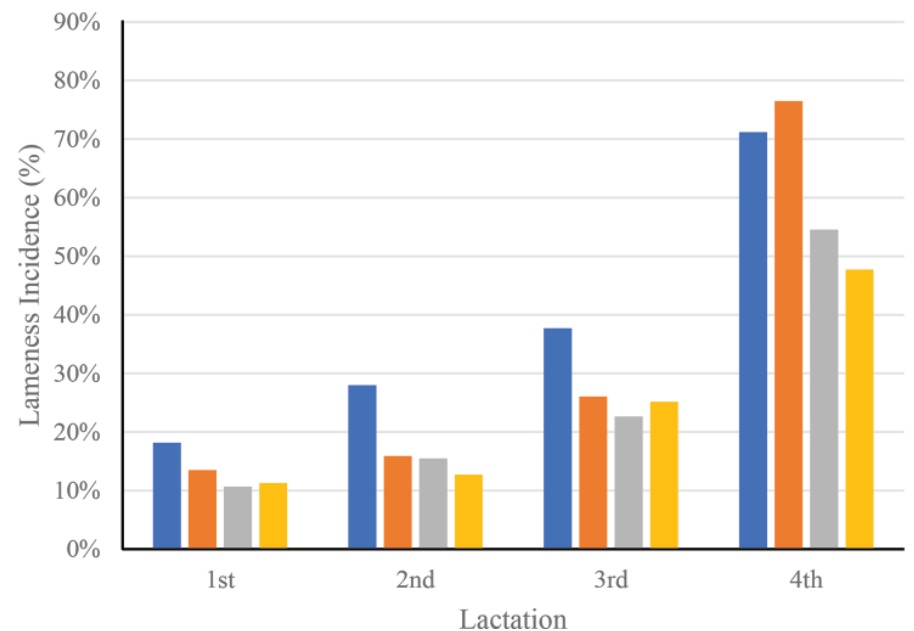

Figure 1. (a) Metritis incidence over 4 lactations when animals are ranked by Dairy Wellness Profit genomically enhanced predicted transmitting ability (gPTA). (b) Mastitis incidence over 4 lactations when animals are ranked by Dairy Wellness Profit gPTA. (c) Lameness incidence over 4 lactations when animals are ranked by Dairy Wellness Profit gPTA. 
address this, we analyzed the difference in the genetic merit of DWP $\$$ and individual traits when animals were ranked by DWP $\$$. We observed a difference in average DWP $\$$ between genetic groups $(P<0.0001)$. As shown in Table 7 , animals in the best DWP $\$$ genetic group had an average DWP $\$$ gPTA of $\$ 430$ and animals in the worst DWP $\$$ genetic group had an average DWP\$ gPTA of $\$ 3$. An animal's DWP $\$$ gPTA prediction was driven by the genetic merit of traits included in DWP $\$$ and economic weight of those traits. In Table 7 we demonstrate differences $(P<0.0001)$ between DWP\$ genetic groups for the following genetic traits: milk, fat, protein, daughter pregnancy rate, cow conception rate, heifer conception rate, calving ability, productive life, cow livability, SCS, mastitis, lameness, metritis, retained placenta, displaced abomasum, and ketosis. This demonstrated that ranking animals by DWP $\$$ predictions will result in increased genetic capability for key underlying traits. This supports the practice of using a selection index to make breeding and culling decisions instead of an individual trait or traits.

As previously discussed, animals in the best DWP $\$$ genetic group expressed more observed lifetime profit than animals in the worst DWP $\$$ genetic group. This is due to DWP\$ identifying animals that are likely to be successful in multiple segments of the dairy operation that affect profit. Income generated by milk, fat, and protein production, live calves born, and an animal's salvage value are the revenue streams for a dairy operation. A selection index needs to maximize these revenue streams by directly selecting for traits that positively affect the revenue streams. Animals in the best DWP $\$$ group have higher genetic potential for milk, fat, and protein traits, which results in more actual milk, fat, and protein income, thus contributing to lifetime profit. Animals in the best DWP $\$$ group have higher genetic potential for fertility traits such as heifer conception rate, cow conception rate, daughter pregnancy rate, and calving ability. The effect of these genetics was evident with more calves born alive in this genetic group. Additionally, the earlier an animal breeds back after calving, the more time that animal spends in peak milk production (Hudson et al., 2018). The value of live calves and more time spent in peak milk are 2 ways genetic selection for fertility traits affects actual lifetime profit. Animals in the best DWP\$ genetic group have higher genetic potential for productive life, which contributes to animals staying in the herd longer. This resulted in more animals in the best DWP\$ genetic group achieving mature-animal milk production (Ray et al., 1992). This is an example of how direct genetic selection for productive life positively affects lifetime profit. Animals in the best DWP\$ genetic group had a higher genetic potential for cow livability, resulting in more animals receiving a salvage value when they leave the herd. An animal's ability to receive a salvage value positively affects her lifetime profit.

Table 7. Average gPTA ${ }^{1}$ or gSTA ${ }^{2}$ of traits and subindices included in Dairy Wellness Profit by genetic group

\begin{tabular}{|c|c|c|c|c|c|}
\hline Item & Worst $25 \%$ & $26-50 \%$ & $51-75 \%$ & Best $25 \%$ & $P$-value \\
\hline Dairy wellness profit $^{1}$ & $3^{\mathrm{a}}$ & $174^{\mathrm{b}}$ & $282^{\mathrm{c}}$ & $430^{\mathrm{d}}$ & $<0.0001$ \\
\hline Milk $^{1}$ & $250^{\mathrm{a}}$ & $382^{\mathrm{b}}$ & $470^{\mathrm{c}}$ & $563^{\mathrm{d}}$ & $<0.0001$ \\
\hline Protein ${ }^{1}$ & $8^{\mathrm{a}}$ & $13^{\mathrm{b}}$ & $16^{\mathrm{c}}$ & $21^{\mathrm{d}}$ & $<0.0001$ \\
\hline Fat $^{1}$ & $11^{\mathrm{a}}$ & $19^{\mathrm{b}}$ & $26^{\mathrm{c}}$ & $36^{\mathrm{d}}$ & $<0.0001$ \\
\hline Productive life $^{1}$ & $0.9^{\mathrm{a}}$ & $1.9^{\mathrm{b}}$ & $2.4^{\mathrm{c}}$ & $3.2^{\mathrm{d}}$ & $<0.0001$ \\
\hline Cow livability ${ }^{1}$ & $-0.4^{\mathrm{a}}$ & $0.5^{\mathrm{b}}$ & $0.8^{\mathrm{c}}$ & $1.4^{\mathrm{d}}$ & $<0.0001$ \\
\hline $\mathrm{SCS}^{1}$ & $2.93^{\mathrm{a}}$ & $2.87^{\mathrm{b}}$ & $2.84^{\mathrm{c}}$ & $2.81^{\mathrm{d}}$ & $<0.0001$ \\
\hline Body size composite $^{1}$ & $0.15^{\mathrm{a}}$ & $-0.02^{\mathrm{b}}$ & $-0.02^{\mathrm{b}}$ & $-0.22^{c}$ & $<0.0001$ \\
\hline Udder composite $^{1}$ & $0.61^{\mathrm{a}}$ & $0.72^{\mathrm{b}}$ & $0.81^{\mathrm{c}}$ & $0.99^{\mathrm{d}}$ & $<0.0001$ \\
\hline Feet and legs composite ${ }^{1}$ & $0.69^{\mathrm{a}}$ & $0.86^{\mathrm{b}}$ & $0.93^{\mathrm{bc}}$ & $0.95^{\mathrm{c}}$ & $<0.0001$ \\
\hline Daughter pregnancy rate ${ }^{1}$ & $0.1^{\mathrm{a}}$ & $0.4^{\mathrm{b}}$ & $0.6^{\mathrm{c}}$ & $0.7^{\mathrm{d}}$ & $<0.0001$ \\
\hline Heifer conception rate ${ }^{1}$ & $0.6^{\mathrm{a}}$ & $0.7^{\mathrm{b}}$ & $0.8^{\mathrm{b}}$ & $1.0^{\mathrm{c}}$ & $<0.0001$ \\
\hline Cow conception rate $e^{1}$ & $0.2^{\mathrm{a}}$ & $0.8^{\mathrm{b}}$ & $1.1^{\mathrm{c}}$ & $1.6^{\mathrm{d}}$ & $<0.0001$ \\
\hline Calving ability $^{1}$ & $7.8^{\mathrm{a}}$ & $14.6^{\mathrm{b}}$ & $17.7^{\mathrm{c}}$ & $22.3^{\mathrm{d}}$ & $<0.0001$ \\
\hline Mastitis $^{2}$ & $94^{\mathrm{a}}$ & $98^{\mathrm{b}}$ & $100^{\mathrm{c}}$ & $103^{\mathrm{d}}$ & $<0.0001$ \\
\hline Lameness $^{2}$ & $97^{\mathrm{a}}$ & $99^{\mathrm{b}}$ & $101^{\mathrm{c}}$ & $102^{\mathrm{d}}$ & $<0.0001$ \\
\hline Metritis $^{2}$ & $96^{\mathrm{a}}$ & $98^{\mathrm{b}}$ & $99^{\mathrm{c}}$ & $100^{\mathrm{d}}$ & $<0.0001$ \\
\hline Retained placenta $^{2}$ & $98^{\mathrm{a}}$ & $100^{\mathrm{b}}$ & $100^{\mathrm{b}}$ & $101^{\mathrm{c}}$ & $<0.0001$ \\
\hline Displaced abomasum $^{2}$ & $98^{\mathrm{a}}$ & $99^{\mathrm{b}}$ & $100^{\mathrm{c}}$ & $101^{\mathrm{d}}$ & $<0.0001$ \\
\hline Ketosis $^{2}$ & $96^{\mathrm{a}}$ & $97^{\mathrm{b}}$ & $98^{\mathrm{b}}$ & $99^{\mathrm{c}}$ & $<0.0001$ \\
\hline Calf respiratory $^{2}$ & $98^{\mathrm{a}}$ & $97^{\mathrm{a}}$ & $97^{\mathrm{a}}$ & $97^{\mathrm{a}}$ & 0.20 \\
\hline Calf scours $^{2}$ & $94^{\mathrm{a}}$ & $93^{\mathrm{ab}}$ & $92^{\mathrm{b}}$ & $93^{\mathrm{ab}}$ & 0.01 \\
\hline Calf livability $^{2}$ & $95^{\mathrm{a}}$ & $94^{\mathrm{a}}$ & $94^{\mathrm{a}}$ & $95^{\mathrm{a}}$ & 0.17 \\
\hline
\end{tabular}

${ }^{a-d}$ Marginal means within row and trait with different superscripts differ $(P<0.05)$.

${ }^{1}$ gPTA $=$ genomically enhanced predicted transmitting ability.

${ }^{2}$ gSTA $=$ genomically enhanced standardized transmitting ability. 
In addition to selecting for traits that directly affect the revenue stream, a selection index needs to directly select for improvement in traits that incur expenses or negatively affect these revenue streams. This will result in optimally maximizing profitability of a dairy operation. Animals in the best DWP $\$$ genetic group have better genetic potential for SCS. As bulk tank SCC decreases, milk production increases (Barkema et al., 1998; Hortet and Seegers, 1998), indicating an opportunity for genetic selection for SCS to affect production, and therefore, lifetime profit. Animals in the best DWP\$ genetic group had more genetic potential for lower disease risk for mastitis, lameness, metritis, retained placenta, displaced abomasum, and ketosis. This resulted in a lower disease prevalence for all 6 traits in animals in the best DWP $\$$ genetic group. Due to the cost of treatment, additional labor, and discarded milk, lower disease prevalence has a positive effect on profit (Guard, 2008a; McArt et al., 2015). Additionally, animals that stay healthy produce more milk throughout their lactations and lifetime (Bar et al., 2007; Bicalho et al., 2008). Overall, the above-mentioned traits are directly selected for in DWP $\$$, and they have a clear effect on actual lifetime profit of an animal.

A selection index consists of many traits that affect profitability combined into a single value developed to predict profitability. In order for a selection index to predict profitability, the relationships between traits needs to be accounted for during selection index development. Traits that affect profitability (and are therefore included in a selection index) can have a positive or a negative genetic correlation between them. An example of a positive genetic correlation is the relationship between milk gPTA and fat gPTA (VanRaden and Cole, 2014). The benefit of this positive genetic correlation is apparent with the best DWP $\$$ genetic group having the highest observed milk production and the highest observed fat production. An example of a negative genetic correlation is the relationship between mastitis gSTA and milk gPTA (Vukasinovic et al., 2017). In our evaluation, the best DWP $\$$ genetic group had the highest observed milk production and the lowest observed mastitis prevalence. This indicated that the combination of traits in DWP $\$$ and the emphasis placed upon those traits predicts how an animal will perform across a multitude of traits, even if they are negatively correlated.

There are not statistically significant differences between DWP $\$$ genetic groups for calf respiratory, calf scours, and calf livability genetic traits. Animals included in this study were genomic tested at an average age of 8.5 mo. This may have created some selection bias, as calves that had poor performance for calf respiratory, calf scours, and calf livability may have already left the herd or were not considered for genomic testing at that time. This could be a contributing factor to why the best DWP $\$$ group does not have higher genetic potential for the 3 calf wellness traits than the worst DWP $\$$ group does. One of the criteria for an animal to be included in the analysis was that she reached first lactation, so additional selection bias likely occurred, as animals that died as calves were not included in this analysis. As such, it was not appropriate to use this data set to thoroughly evaluate the association between calf scours, calf respiratory disease, and calf mortality phenotypes and DWP $\$$ genetic groups.

Overall genetic selection using DWP\$ resulted in an increase in genetic potential for many of the underlying traits in the selection index and an increase in the corresponding observed phenotypic performance of those variables.

\section{Potential Use of Selection Index Beyond Genetics Programs}

In the future, this type of analysis can help us better understand what traits affect lifetime profitability and improve selection index development. Continuing to improve the predictive power of selection indices generates the potential to incorporate selection indices into additional on-farm management decisions beyond breeding and heifer culling decisions in the future. There is a potential for, when combined with additional predictive algorithms and precision data, selection indices to be incorporated into individual animal treatment and culling models.

Some dairy producers and researchers have started exploring the combination of different management strategies with genetic predictions to enhance protocols and animal performance. O'Sullivan et al. (2019) evaluated the ability of animals of different EBI genetic merit to perform depending on the ration they were fed. Although the authors did not report any significant interaction between genetic merit and ration on production, this could be an interesting relationship to continue to explore. It would be useful to evaluate if DWP $\$$ values are more effective predictors of lifetime profit when matched with specific and different management strategies.

\section{CONCLUSIONS}

The observed results of this evaluation demonstrated the ability of DWP $\$$ predictions to predict significant $(P<0.0001)$ differences in estimated lifetime profit of Holstein animals. These results also demonstrated the ability of DWP $\$$ genetic predictions to predict significant $(P \leq 0.0002)$ differences in phenotypic per- 
formance for lifetime milk production, lifetime fat production, lifetime protein production, lifetime number of live calves produced, longevity, and lifetime disease incidence for mastitis, lameness, and metritis. These results indicated that genomically-enhanced DWP\$ predictions for young calves can be used to effectively predict future lifetime profitability. Improving DWP\$ through genetic selection, when combined with good management practices, provides an opportunity for dairy producers to improve overall herd profitability. Dairy Wellness Profit predictions are a useful tool for dairy producers interested in using genetics as a method to improve their overall herd profitability. Incorporating DWP\$ into breeding and culling decisions will help dairy producers create future generations of animals that have higher lifetime profitability when combined with best management practices.

\section{ACKNOWLEDGMENTS}

The authors thank the management teams of the enrolled farms for access to their cows and production records and the editors and reviewers of the Journal of Dairy Science for their efforts performing peer review of this manuscript. This research was conducted as a part of the authors' employment with Zoetis LLC, furthering the scientific research related to the CLARIFIDE Plus product sold by Zoetis.

\section{REFERENCES}

Bar, D., Y. T. Grohn, G. Bennett, R. N. Gonzalez, J. A. Hertl, H. F. Schulte, L. W. Tauer, F. L. Welcome, and Y. H. Schukken. 2007. Effect of repeated episodes of generic clinical mastitis on milk yield in dairy cows. J. Dairy Sci. 90:4643-4653. https://doi .org/10.3168/jds.2007-0145.

Bar, D., L. Tauer, G. Bennett, R. Gonzalez, J. Hertl, Y. Schukken, H. Schulte, F. Welcome, and Y. Gröhn. 2008. The cost of generic clinical mastitis in dairy cows as estimated by using dynamic programming. J. Dairy Sci. 91:2205-2214. https://doi.org/10.3168/ jds.2007-0573.

Barkema, H. W., Y. H. Schukken, T. J. Lam, M. L. Beiboer, G. Benedictus, and A. Brand. 1998. Management practices associated with low, medium, and high somatic cell counts in bulk milk. J. Dairy Sci. 81:1917-1927. https://doi.org/10.3168/jds.S0022 -0302(98)75764-9.

Bicalho, R. C., L. D. Warnick, and C. L. Guard. 2008. Strategies to analyze milk losses caused by diseases with potential incidence throughout the lactation: A lameness example. J. Dairy Sci. 91:2653-2661. https://doi.org/10.3168/jds.2007-0744.

Boettcher, P. J., L. B. Hansen, H. Chester-Jones, and C. W. Young. 1993. Responses of yield and conformation to selection for milk in a designed experiment with a control population. J. Dairy Sci. 76:267-273. https://doi.org/10.3168/jds.S0022-0302(93)77345-2.

Boichard, D., H. Chung, R. Dassonneville, X. David, A. Eggen, S. Fritz, K. J. Gietzen, B. J. Hayes, C. T. Lawley, T. S. Sonstegard, C. P. Van Tassell, P. M. VanRaden, K. A. Viaud-Martinez, and G. R. Wiggans. 2012. Design of a bovine low-density SNP array optimized for imputation. PLoS One 7:e34130. https://doi.org/10 $.1371 /$ journal.pone. 0034130 .
Brealey, R. A., S. C. Myers, F. Allen, and P. Mohanty. 2012. Principles of Corporate Finance. 10th ed. McGraw-Hill, New York, NY.

Byrne, T. J., B. F. S. Santos, P. R. Amer, D. Martin-Collado, J. E. Pryce, and M. Axford. 2016. New breeding objectives and selection indices for the Australian dairy industry. J. Dairy Sci. 99:81468167. https://doi.org/10.3168/jds.2015-10747.

Cha, E., D. Bar, J. Hertl, L. Tauer, G. Bennett, R. González, Y. Schukken, F. Welcome, and Y. Gröhn. 2011. The cost and management of different types of clinical mastitis in dairy cows estimated by dynamic programming. J. Dairy Sci. 94:4476-4487. https://doi .org/10.3168/jds.2010-4123.

Cha, E., A. R. Kristensen, J. A. Hertl, Y. H. Schukken, L. W. Tauer, F. L. Welcome, and Y. T. Grohn. 2014. Optimal insemination and replacement decisions to minimize the cost of pathogen-specific clinical mastitis in dairy cows. J. Dairy Sci. 97:2101-2117. https:/ /doi.org/10.3168/jds.2013-7067.

Cole, J. B., and P. M. VanRaden. 2018. Symposium review: Possibilities in an age of genomics: The future of selection indices. J. Dairy Sci. 101:3686-3701. https://doi.org/10.3168/jds.2017-13335.

Dekkers, J. C., and J. P. Gibson. 1998. Applying breeding objectives to dairy cattle improvement. J. Dairy Sci. 81(Suppl 2):19-35. https://doi.org/10.3168/jds.S0022-0302(98)70151-1.

DHIA. 2000. Energy Corrected Milk. Accessed Jan. 27, 2020. https: // dairymarkets.org/PubPod/Reference/Library/Energy\%20 Corrected\%20Milk.

Dhuyvetter, K. C., T. L. Kastens, M. Overton, and J. Smith. 2007. Cow culling decisions: Costs or economic opportunity. Pages 173188 in Proc. Western Dairy Management Conference, Reno, NV. http://wdmc.org/2007/WDMC\%202007.pdf.

Dhuyvetter, K. C., and M. Overton. 2017. Economic considerations regarding the raising of dairy replacement heifers. Page 18 in Large Dairy Herd Management. 3rd ed. D. K. Beede, ed. American Dairy Science Association, Champaign, IL.

Dohoo, I. R., W. Martin, and H. Stryhn. 2003. Veterinary epidemiologic research. 2nd ed. Ver Inc. Charlottetown, Canada.

Galligan, D. 2006. Economic assessment of animal health performance. Vet. Clin. North Am. Food Anim. Pract. 22:207-227. https://doi .org/10.1016/j.cvfa.2005.11.007.

Galligan, D., and F. Wu. 2013. Dairy Dashboard. UPENN 2012, Center for Animal Health and Productivity. Accessed Jun. 15, 2019. http://dgalligan.com/fieldservice/dashboard.html.

Galvão, K. N., P. Federico, A. De Vries, and G. M. Schuenemann. 2013. Economic comparison of reproductive programs for dairy herds using estrus detection, timed artificial insemination, or a combination. J. Dairy Sci. 96:2681-2693. https://doi.org/10.3168/ jds.2012-5982.

García-Ruiz, A., J. B. Cole, P. M. VanRaden, G. R. Wiggans, F. J. Ruiz-López, and C. P. Van Tassell. 2016. Changes in genetic selection differentials and generation intervals in US Holstein dairy cattle as a result of genomic selection. Proc. Natl. Acad. Sci. USA 113:E3995-E4004. https://doi.org/10.1073/pnas.1519061113.

Gay, K. D., N. J. Widmar, T. D. Nennich, A. P. Schinckel, J. B. Cole, and M. M. Schutz. 2014. Development of a Lifetime Meritbased selection index for US dairy grazing systems. J. Dairy Sci. 97:4568-4578. https://doi.org/10.3168/jds.2013-7474.

Gonzalez-Peña, D., N. Vukasinovic, J. Brooker, C. Przybyla, and S. DeNise. 2019. Genomic evaluation for calf wellness traits in Holstein cattle. J. Dairy Sci. 102:2319-2329. https://doi.org/10.3168/ jds.2018-15540

Guard, C. 2008a. The costs of common diseases of dairy cattle. Proc. CVC. San Diego, CA. https://www.dvm360.com/view/costs -common-diseases-dairy-cattle-proceedings.

Guard, C. 2008b. Lameness control strategies and economics. Proc. Ontario Veterinary Medical Association, Toronto, Ontario.

Hazel, L. N. 1943. The genetic basis for constructing selection indexes. Genetics 28:476-490.

Hill, W. G. 2016. Is continued genetic improvement of livestock sustainable? Genetics 202:877-881. https://doi.org/10.1534/genetics .115 .186650 . 
Hortet, P., and H. Seegers. 1998. Calculated milk production losses associated with elevated somatic cell counts in dairy cows: Review and critical discussion. Vet. Res. 29:497-510.

Hudson, C., J. G. Cook, and R. Laven. 2018. Veterinary control of herd fertility in intensively managed dairy herds. Page 467 in Arthur's Veterinary Reproduction and Obstetrics-E-Book. Elsevier, United Kingdom.

McArt, J. A., D. V. Nydam, and M. W. Overton. 2015. Hyperketonemia in early lactation dairy cattle: A deterministic estimate of component and total cost per case. J. Dairy Sci. 98:2043-2054. https://doi.org/10.3168/jds.2014-8740.

McNeel, A. K., B. C. Reiter, D. Weigel, J. Osterstock, and F. A. Di Croce. 2017. Validation of genomic predictions for wellness traits in US Holstein cows. J. Dairy Sci. 100:9115-9124. https://doi.org/ 10.3168 /jds.2016-12323.

Miglior, F., B. Muir, and B. Van Doormaal. 2005. Selection indices in Holstein cattle of various countries. J. Dairy Sci. 88:1255-1263. https://doi.org/10.3168/jds.S0022-0302(05)72792-2.

Misztal, I., A. Legarra, and I. Aguilar. 2009. Computing procedures for genetic evaluation including phenotypic, full pedigree, and genomic information. J. Dairy Sci. 92:4648-4655. https://doi.org/10 $.3168 /$ jds.2009-2064.

Misztal, I., A. Legarra, and I. Aguilar. 2014. Using recursion to compute the inverse of the genomic relationship matrix. J. Dairy Sci. 97:3943-3952. https://doi.org/10.3168/jds.2013-7752.

National Research Council. 2001. Nutrient Requirements of Dairy Cattle. 7th rev. ed. Natl. Acad. Press, Washington, DC

Newton, J., M. Goddard, H. Phuong, M. Axford, C. Ho, N. Nelson, C. Waterman, B. Hayes, and J. Pryce. 2017. High genetic merit dairy cows contribute more to farm profit: Case studies of 3 Australian dairy herds. Proc. Advmt. Anim. Breed. Genet. 22:19-22.

O'Sullivan, M., B. Horan, K. M. Pierce, S. McParland, K. O'Sullivan, and F. Buckley. 2019. Milk production of Holstein-Friesian cows of divergent Economic Breeding Index evaluated under seasonal pasture-based management. J. Dairy Sci. 102:2560-2577. https:// doi.org/10.3168/jds.2018-15559.

Overton, M., and J. Fetrow. 2008. Economics of postpartum uterine health. Pages 39-44 in Proc. Dairy Cattle Reproduction Council Annu. Meet., Omaha, NE. Dairy Cattle Reproduction Council, New Prague, MN

Pedersen, J., M. K. Sørensen, M. Toivonen, J. Eriksson, and G. P. Aamand. 2008. Report on economic basis for a Nordic total merit index in Report from Nordic Cattle Genetic Evaluation. Nordisk Avlsvaerdi Vurdering, Aarhus, Denmark.

Ramsbottom, G., A. Cromie, B. Horan, and D. P. Berry. 2012. Relationship between dairy cow genetic merit and profit on commercial spring calving dairy farms. Animal 6:1031-1039. https://doi.org/ 10.1017/S1751731111002503.

Ray, D. E., T. J. Halbach, and D. V. Armstrong. 1992. Season and lactation number effects on milk production and reproduction of dairy cattle in Arizona. J. Dairy Sci. 75:2976-2983. https://doi .org/10.3168/jds.S0022-0302(92)78061-8.

Sargolzaei, M., J. P. Chesnais, and F. S. Schenkel. 2014. A new approach for efficient genotype imputation using information from relatives. BMC Genomics 15:478. https://doi.org/10.1186/1471 $-2164-15-478$.

Schneeberger, M., S. Barwick, G. Crow, and K. Hammond. 1992. Economic indices using breeding values predicted by BLUP. J. Anim. Breed. Genet. 109:180-187. https://doi.org/10.1111/j.1439-0388 .1992.tb00395.x.

Schutz, M. M. 1994. Genetic evaluation of somatic cell scores for United States dairy cattle. J. Dairy Sci. 77:2113-2129. https://doi.org/ 10.3168/jds.S0022-0302(94)77154-X.
Shook, G. E. 2006. Major advances in determining appropriate selection goals. J. Dairy Sci. 89:1349-1361. https://doi.org/10.3168/jds .S0022-0302(06)72202-0.

Smith, C. 1983. Effects of changes in economic weights on the efficiency of index selection. J. Anim. Sci. 56:1057-1064.

Tyrrell, H. F., and J. Reid. 1965. Prediction of the energy value of cow's milk. J. Dairy Sci. 48:1215-1223. https://doi.org/10.3168/ jds.S0022-0302(65)88430-2 https://doi.org/10.3168/jds.S0022 $-0302(65) 88430-2$.

USDA-AMS. 2016. National Dairy Promotion \& Research Board. Accessed Jan. 26, 2020. https://www.ams.usda.gov/rules-regulations/ research-promotion/dairy.

USDA-AMS. 2020. Announcement of Class and Component Prices. Accessed Feb. 5, 2020. https://www.ams.usda.gov/mnreports/ dymclassprices.pdf.

USDA-NASS. 2019. Prices Received for Cattle by Month - United States. Accessed Dec. 15, 2019. https://www.nass.usda.gov/ Charts_and_Maps/Agricultural_Prices/priceca.php.

VanRaden, P. M. 2004. Invited review: Selection on net merit to improve lifetime profit. J. Dairy Sci. 87:3125-3131. https://doi.org/ 10.3168/jds.S0022-0302(04)73447-5.

VanRaden, P. M., and J. B. Cole. 2014. Net merit as a measure of lifetime profit: 2014 revision. AIPL Research Report NM\$5 (10-14). Accessed Jun. 15, 2016. https://aipl.arsusda.gov/reference/nmcalc -2014.htm.

VanRaden, P. M., J. B. Cole, and K. L. Parker Gaddis. 2018. Net merit as a measure of lifetime profit: 2018 revision. AIPL Research Report NM\$7 (5-18). Accessed Aug. 15, 2018. https://aipl.arsusda gov/reference/nmcalc-2018.htm.

VanRaden, P. M., A. H. Sanders, M. E. Tooker, R. H. Miller, H. D. Norman, M. T. Kuhn, and G. R. Wiggans. 2004. Development of a national genetic evaluation for cow fertility. J. Dairy Sci. 87:22852292. https://doi.org/10.3168/jds.S0022-0302(04)70049-1.

VanRaden, P. M., and G. R. Wiggans. 1995. Productive life evaluations: Calculation, accuracy, and economic value. J. Dairy Sci 78:631-638. https://doi.org/10.3168/jds.S0022-0302(95)76674-7.

Vukasinovic, N., N. Bacciu, C. A. Przybyla, P. Boddhireddy, and S. K. DeNise. 2017. Development of genetic and genomic evaluation for wellness traits in US Holstein cows. J. Dairy Sci. 100:428-438. https://doi.org/10.3168/jds.2016-11520.

Weigel, K. A., P. C. Hoffman, W. Herring, and T. J. Lawlor Jr. 2012. Potential gains in lifetime net merit from genomic testing of cows, heifers, and calves on commercial dairy farms. J. Dairy Sci. 95:2215-2225. https://doi.org/10.3168/jds.2011-4877.

Zoetis, U. S. 2018. Impact of Dairy Cow Body Weight Variation on Correct Dosing of EXCEDE and EXCENEL RTU EZ. Accessed Jun. 15, 2019. https://www.zoetisus.com/products/dairy/excede -dairy/docs/pdf/exd-00054_excede-excenel_body_weight_dosing _technical_bulletin.pdf.

Zoetis, U. S. 2020. CLARIFIDE Plus Information Page. Accessed Dec. 25, 2020. https://www.zoetisus.com/animal-genetics/dairy/index .aspx.

\section{ORCIDS}

Brenda Fessenden () https://orcid.org/0000-0001-5620-5716 Fernando Di Croce ำ https://orcid.org/0000-0002-2868-7655 